\title{
E-Banking Customer Satisfaction and Loyalty: Evidence from Serial Mediation through Modified E-S-QUAL Model and Second-Order PLS-SEM
}

\author{
Rizwan Raheem Ahmed ${ }^{1}$, Dalia Streimikiene ${ }^{2, *}$, Zahid Ali Channar ${ }^{3}$, Riaz Hussain Soomro ${ }^{4}$, \\ Justas Streimikis ${ }^{5,6}$
}

${ }^{1}$ Faculty of Management Sciences, Indus University

Block-17, Gulshan, Karachi, Pakistan

E-mail.rizwanraheemahmed@gmail.com

${ }^{2}$ Lithuanian Sports University, Institute of Sport Science and Innovations

Sporto str. 6, Kaunas, Lithuania

E-mail.dalia@mail.lei.lt; *correspondingauthor

${ }^{3}$ Department of Business Administration, Sindh Madressatul Islam University

Karachi-74000, Pakistan

E-mail.drzahidalic@gmail.com

${ }^{4}$ Institute of Health Management, Dow University of Health Sciences

Mission Road, Karachi-74200, Pakistan

E-mail.riaz.soomro@duhs.edu.pk

${ }^{5}$ Lithuanian Centre for Social Sciences, Institute of Economics and Rural Development

A. Vivulskio g. 4A-13, LT-03220 Vilnius, Lithuania

${ }^{6}$ Faculty of Management and Finances, University of Economics and Human Science in Warsaw

Okopowa 59, 01-043Warsaw, Poland

E-mail.jutas.streimikis@gmail.com

cross'ref http://dx.doi.org/10.5755/j01.ee.32.5.28997

This research aims to measure the service quality of e-banking through e-customer satisfaction \& e-customer loyalty in the Islamic e-banking sector of Pakistan. For this purpose, we modified the multiple-item scale (E-S-QUAL) model with two new dimensions: availability of online system and personal needs of customers. Additionally, we added two mediators, for instance, religiosity and trust in the Islamic e-banking perspective. We have collected 674 responses from the consumers of the Islamic banking sector of Pakistan through a structured questionnaire. The data were analysed through second-order PLS-SEM (PLS-structural equation modeling) to examine direct and serial mediation. The direct relationship results showed a positive and compelling effect of modified E-S-QUAL dimensions on e-customer satisfaction. Additionally, the e-customer satisfaction has an affirmative and significant association with e-customer loyalty. Moreover, the serial mediation relationship results exhibited that the e-customer satisfaction, trust, and religiosity mediated the modified dimensions of the E-S-QUAL model and e-customer loyalty.

Keywords: Modified E-S-QUAL Mode; E-Customer Loyalty; E-Customer Satisfaction; Serial Mediation; E-Islamic Banking; PLS-SEM (Partial Least Square - Structural Equation Modeling); Smart-PLS (Partial Least Square) Software.

\section{Introduction}

E-Islamic banking follows Islam's basic Shariah principles and laws. According to Islam, Pakistani and Malaysian Islamic banks strictly observe the Shariah laws (Singh, 2019; Ahmed et al., 2020; Dusuki \& Abdullah, 2007). However, e-Islamic banking of Iran, UAE, Bahrain, Qatar, and Saudi Arabia are also functioning on the fundamentals of Islamic Shariah laws. According to Zouari and Abdelhedi (2021), Ali and Raza (2017), Amin et al. (2014), and Raza et al. (2020), customers are attracted to eIslamic banking due to e-financial benefits and religious faith. Additionally, the customers relate to e-Islamic banking due to compliance with Shariah laws, social influence, customer's needs, and operational cost (Sleimi et al., 2020; Ahmed et al., 2019; Raza et al., 2019). The preceding literature demonstrated that customers are shifted towards e-Islamic banking for numerous reasons, such as eservice quality, location, religious beliefs, financial benefits, and Shariah laws compliance (Yaseen \& Kamran, 2019; Raza et al., 2015; Dusuki \& Abdullah, 2007). According to Dusuki and Abdullah (2007) and Ahmed et al. (2019), the crucial factors of e-Islamic banking are subjective norms, behavioural control, and attitude. However, Amin et al. (2014) opposed the conflict between conventional ebanking and Islamic e-banking and emphasized identifying Islamic e-banking services' factual antecedents. 
Flores et al. (2020), Butt (2018), Parasuraman and Zeithaml (2002), Yaseen and Kamran (2019), and Devaraj et al. (2002) have emphasized the significance and vibrant functions of service quality in different industries. Traditionally, the SERVQUAL model was used to measure customer satisfaction and perceived quality (Ahmed et al., 2017; Raza et al., 2015). Previous literature has exhibited that the dimensions of the SERVQUAL model are one of the adequate tools to measure customer satisfaction and customer loyalty in e-service industries (Dewi \& Surabaya, 2020; Devaraj et al., 2002; Ahmed et al., 2017; Raza et al., 2020). The Internet \& digital media have enhanced the effectiveness of the SERVQUAL model, and customers are moving towards e-commerce, e-banking, and online shopping. Thus, the adaptation of the SERVQUAL model is inescapable to evaluate the e-service quality in cybernetic markets (Al Qaisi \& Alrosan, 2020; Raza et al., 2019). Therefore, a group of eminent researchers, Parasuraman et al. (2005), proposed an adapted electronic service quality (E-S-QUAL) model with multiple indicators to evaluate e-service quality effectiveness in a real-time interface. The conventional SERVQUAL model comprises of five standard constructs: 1) reliability, 2) assurance, 3) tangible, 4) responsiveness and 5) empathy with 22 items. However, the proposed E-S-QUAL model of Parasuraman et al. (2005) provided four constructs, such as 1) availability of the online system, 2) efficiency, 3) fulfillment, and 4) security \& privacy measuring scales. The new E-S-QUAL tool as fulfillment-service quality in different online services has different features, such as privacy, secures the customers' information \& data, and evaluates the speed \& ease of online interface efficacy. However, fulfillment evaluates the website application, operation, and performance. The online system availability comprises technical infrastructure and websites' effectiveness (Ahmed et al., 2020; Ali \& Raza, 2017). The Internet has become the most powerful tool for e-commerce and eservices; therefore, e-services industries, including ebanking, use this instrument as a virtual marketplace. The esystem quality and information of e-services quality have become significant elements of the E-S-QUAL model to assess the e-service quality, e-customer satisfaction, and ecustomer loyalty in online services industries (Dewi \& Surabaya, 2020; Samsudeen et al., 2020; Rodgers et al., 2005; Vinayek \& Jindal, 2011).

The Islamic e-banking sector of Pakistan successfully challenged the developed global e-banking system. This sector implements innovative Islamic e-banking operations methods for e-customer satisfaction and e-customer loyalty (Raza et al., 2019). According to Ahmed et al. (2019), Pakistani Islamic banks have incorporated e-services and converted from conventional interfaces to e-banking systems. According to Azizah and Puspito (2021), Raza et al. (2015), and Pikkarainen et al. (2006), Gardener et al. (1999), the ebanking system is effective and efficient, which enhance revenue growth, increase geographic markets, reduces cost, and provides customer's satisfaction. Similarly, the Islamic ebanking sector of Pakistan offers supreme quality through ebanking services to create excellent opinions in customer's minds. Indeed, the finest quality e-services lead to ecustomers satisfaction, e-customer retention, and e-customer loyalty. Satisfied customers can further enhance the pool of customers and corporate image (Lodhi, 2020; Caruana, 2002;
Cronin \& Taylor, 1992). Previous literature demonstrated the effectiveness of the corporate banking system, but there is a shortage of information regarding the Islamic e-banking system in Pakistan. Thus, the undertaken study is conducted to evaluate the electronic service quality of Islamic banks, ecustomer satisfaction, and e-customer loyalty in Pakistani Islamic banks' electronic service quality.

Additionally, this research evaluates the Islamic ebanking services and how customers appraise the Islamic ebanking services in an online environment. The significance of this research has increased during pandemic COVID-19 when people are shifted towards online purchases and online banking systems. The undertaken study employed a modified E-S-QUAL model to examine customer satisfaction and customer loyalty. We also incorporated trust and religiosity as mediating constructs in the perspective of the Islamic banking sector. Previous literature demonstrated the inconclusive results amid multidimensional E-S-QUAL models and examining the mediation. We measured the serial mediation between modified E-S-QUAL dimensions and customer satisfaction \& e-customer loyalty. The findings of this research provide significant practical implications to the senior managers of the Islamic banking sector for applying robust marketing strategies to compete with conventional ebanking systems.

\section{Literature Review and Hypotheses Development}

\section{The Islamic E-Banking}

The conception of Islamic banking has become a prominent feature of Islamic societies, and the Islamic banking sector grows in the developing and developed world. The Islamic banks have introduced several products, which surpassed the conventional banking system (Lodhi, 2020). The Islamic banking sector has provided several alternative products consistent with the Islamic Shariah laws compared to the conventional banking sector. Islamic banking has recorded phenomenal financial growth worldwide (Azizah \& Puspito, 2021; Metawa \& Almossawi, 1998). Like conventional e-banking, Islamic e-banking is a way to perform an online transaction through an internet portal to avail various Islamic e-banking facilities in realtime, for example, online fund transfer, utility bills payment, e-shopping, banking instruments requests, and E-purse facilities, etc. (Zouari \& Abdelhedi, 2021).

\section{Islamic E-Banking Service Quality}

According to Azizah and Puspito (2021) and Ali and Raza (2017), e-service quality is very relevant to the Islamic e-banking sector because of the online banking services. Previous literature precisely discussed Islamic e-banking and electronic service quality. Previous literature demonstrated a customer's view regarding the e-service quality of Islamic e-banking services. Previous researches also measured the e-service quality of conventional ebanking, for instance, Siu and Mou (2005), Bauer et al. (2005), and Shao et al. (2009). Similarly, previous studies also examined the electronic service quality of the Islamic e-banking sector, such as Raza et al. (2015), Ahmed et al. (2020), Butt (2018), Sohail, and Shaikh (2008), and Khan et al. (2009). This study is unique in a way, which measuring 
the Islamic e-banking service quality through modified E-SQUAL dimensions with religiosity and trust as the mediators in the Islamic e-banking sector.

\section{E-Customer Satisfaction}

Customer satisfaction is experienced or achieved through the medium of electronic or online setting, which is regarded as e-customer satisfaction (Zeithaml, 2002). Additionally, accomplishing the expectancies and necessities of a consumer in e-commerce varies with time due to the unique knowledge and exposure of e-customers (Hayati et al., 2020; Zeithaml et al., 2002). E-customer satisfaction is the customer's assessment regarding the etransaction in comparison to conventional transactions. According to Boateng et al. (2021), Evanschitzky et al. (2004), and Samsudeen et al. (2020), the significant difference between e-retailing and traditional retailing services is transforming man to machine or transactions through artificial intelligence through the Internet. Therefore, for e-customer satisfaction, modified \& innovative improvements are required, and this research bridges the gap between e-customers satisfaction and ecustomer loyalty. Previous literature has shaped a substantial research work on e-customer satisfaction, which pointed out numerous elements, for instance, websites characteristics, technology, product characteristics, and shopping, are essential for e-customer satisfaction (Al Qaisi \& Alrosan, 2020; Yaseen \& Kamran, 2019; Azizah \& Puspito, 2021).

\section{E-Customers Loyalty}

E-customer loyalty is primarily associated with online customers through tackling their queries and concerns regarding Islamic e-banking. The significance of Islamic ebanking enhances as additional consumers utilize Internet networks in connection with their bank accounts (Sleimi et al., 2020; Singh, 2019; Raza et al., 2020). Our considered modified E-S-QUAL model is significant to enhance ecustomer loyalty. Islamic e-banking provides less service cost, ease in transactions, and saves time. According to Lodhi (2020) and Aghdaie et al. (2015), when information quality and system quality are remarkable in Islamic ebanking, in response, e-customer satisfaction and ecustomer loyalty will enhance. Previous literature emphasized the importance of Islamic e-banking as it permits customers can do transactions 24/7 without any hindrances by observing Islamic Laws. According to Boateng et al. (2021), Butt (2018), Iqbal (2020), Dewi and Surabaya (2020), and Nguyen and Leblanc (2002), ecustomer loyalty increases when customer frequently uses e-banking services with satisfaction. Hence, it demonstrated that e-customer satisfaction is directly associated with ecustomer loyalty. Thus, we framed the hypothesis as below:

H1: E-customer satisfaction has a significant \& positive connection with e-customer loyalty.

\section{E-Customers Satisfaction and Modified E-S-QUAL Model}

A group of eminent researchers, such as Parasuraman et al. (2005), proposed an adapted electronic service quality (E-S-QUAL) model with multiple indicators to evaluate e- service quality effectiveness in a real-time interface. However, the proposed E-S-QUAL model of Parasuraman et al. (2005) provided four constructs: availability of the online system, efficiency, fulfillment, and security \& privacy with 22 measuring scales. The new E-S-QUAL tool provided different online services features, such as privacy, secure the customer's information \& data, and evaluates the speed \& ease of online interface efficacy (Zeithaml et al., 2000). However, fulfillment estimates the website application, operation \& performance. The online system availability comprises the technical infrastructure and effectiveness of websites (Kumar \& Mokha, 2021; Azizah \& Puspito, 2021; Raza et al., 2020). E-S-QUAL model, esystem quality, information, and e-services quality have become significant elements to evaluate the electronic service quality of e-customers satisfaction and e-customer loyalty in online services industries (Rahmawati \& Sentana, 2021; Chang et al., 2009; Vinayek \& Jindal, 2011; Rodgers et al., 2005). The current research evaluates the Islamic ebanking services and how customers evaluate the Islamic ebanking services in an online environment (Al Qaisi \& Alrosan, 2020; Yaseen \& Kamran, 2019). The undertaken study employed modified E-S-QUAL system dimensions to examine the customer's satisfaction \& customer's loyalty.

\section{Hypothesized Direct Relationship}

The current study incorporated modified dimensions such as efficiency, security \& privacy, fulfillment, availability of the online system, and personal needs of the E-S-QUAL model and evaluate the influence of these dimensions on e-customer satisfaction and e-customer loyalty. Previous literature such as Raza et al. (2020), Lodhi (2020), Wu and Chang (2013), Chen and Hitt (2002), and Kheng (2010) demonstrated that efficiency has a significant $\&$ positive impact on e-customer satisfaction. Similarly, Yaseen and Kamran (2019), Yen and Lu (2008), Garzaro et al. (2020), Amin (2016), Singh and Kaur (2013), and Sakhaei et al. (2014) exhibited that security \& privacy has a significant and affirmative association with e-customer satisfaction. Previous studies also demonstrated an affirmative and significant association between fulfillment and e-customer satisfaction (Kumar \& Mokha, 2021; Singh, 2019; Mahadin et al., 2020; Hammoud et al., 2018; Rajaobelina et al., 2019; Sheng \& Leu, 2010; Ali \& Raza, 2017; Ahmed et al., 2019; Chen, 2013). Preceding studies, for instance, Hammoud et al. (2018), Ho et al. (2012), Raza et al. (2019), Ahmed et al. (2020), Suleman et al. (2012), and Amin (2016) have confirmed that the availability of online system has a significant and positive influence on ecustomer satisfaction. Finally, studies such as Tanim et al. (2021), Raza et al. (2019), Brodie (2002), Yoon (2010), Kekar et al. (2020), Rahmawati and Sentana (2021), and Amin (2016) have demonstrated that personal needs of customers have an affirmative and significant relationship with e-customer satisfaction. Thus, we formulated the following hypotheses:

H2: The efficiency dimension has a significant \& positive relationship with e-customer satisfaction.

H3: Security \& privacy dimension has a significant \& positive relationship with e-customer satisfaction. 
H4: The fulfillment dimension has a significant \& positive relationship with e-customer satisfaction.

H5: Availability of online system dimension has a significant \& positive relationship with e-customer satisfaction.

H6: Personal needs dimension has a significant \& positive relationship with e-customer satisfaction.

\section{Hypothesized Indirect Relationship}

We also incorporated trust and religiosity as mediating constructs in our considered E-S-QUAL model in the perspective of Islamic e-banking. We measured the serial mediation between modified E-S-QUAL dimensions and ecustomer satisfaction and e-customer loyalty.

\section{Customer's Trust}

For e-banking services, trust is the vital element; if the promised features and benefits exceed or at least meet the customer's expectations, the trust establishes between the consumer and organization (Samsudeen et al., 2020; Mayer et al., 1995). In an online services industry or Islamic ebanking industry, trust always plays a significant function in e-transactions where insecurity is widespread, and it is challenging to measure the quality of online products or services before purchase (Kim et al., 2009; Fang et al., 2011; Al Qaisi \& Alrosan, 2020; Flores et al., 2020; Palvia, 2009). According to Yousafzai et al. (2009), e-banking has a novel dimension of customer's trust due to intrinsic uncertainty of e-transaction, the widespread use of technology, and the careful nature of e-atmosphere. The customer's trust builds on several elements: perceived privacy perceived security, and perceived trustworthiness, especially in Islamic e-banking transactions (Rahmawati \& Sentana, 2021; Godwin et al., 2010; Ahmed et al., 2020; Dimitriadis et al., 2011). According to Ahmad and Al-Zubi (2011), Singh (2019), Crumlish and Malone (2009), and Siam (2006), in e-banking transactions, the customer's trust has a multidimensional perception. Customer's trust played a significant mediating role between modified E-S-QUAL dimensions and e-customer satisfaction and e-customer loyalty. Hence, the following hypotheses are framed:

H7A: Trust has a significant and positive serial mediation between efficiency dimension, e-customer satisfaction, and e-customer loyalty.

H7B: Trust has a significant and positive serial mediation between security \& privacy dimension, ecustomer satisfaction, and e-customer loyalty.

H7C: Trust has a significant and positive serial mediation between fulfillment dimension, e-customer satisfaction, and e-customer loyalty.

H7D: Trust has a significant and positive serial mediation between the availability of online system dimension, e-customer satisfaction, and e-customer loyalty.

H7E: Trust has a significant and positive serial mediation between personal needs dimension, e-customer satisfaction, and e-customer loyalty.

H7F: Trust is a significant \& positive mediating construct between e-customer satisfaction and e-customer loyalty.

\section{Religiosity}

Several research studies have identified customer's religiosity and concluded that this is a significant factor influencing customer's purchasing behavior (Dodds et al., 1991). The imminence of action and factual existence towards the possession and use of products and services is affected by religious practices (Shaharudin et al., 2010). Religiosity has an immediate connection with consumer behavior, a core point in every belief. Therefore, an exploration of religiosity enables a detailed examination of consumer behavior (Yaseen \& Kamran, 2019; Rakrachakarn et al., 2015). There is sufficient literature available regarding the correlation between religiosity and the actions of customers. In the modified E-S-QUAL model, we embedded 'religious belief' as a mediator, an essential component in Islamic e-banking. In traditional banking, interest is an integral element (Butt, 2018; Vitell, 2009). The interest rate is forbidden in Islamic values; therefore, religious belief is fundamental in choosing Islamic ebanking services. Religious belief is a fundamental component for clients who decide on any Islamic banking product (Flores et al., 2020; Bukhari et al., 2020; Dusuki \& Abdullah, 2007). Previous literature demonstrated that religious belief is a significant construct in the Islamic ebanking sector (Lodhi, 2020; Ahmed et al., 2019; Haron et al., 1994). Therefore, based on previous studies, we framed the following hypotheses:

H8A: Religiosity has an affirmative \& significant serial mediation between efficiency, e-customer satisfaction, and e-customer loyalty.

H8B: Religiosity has an affirmative \& significant serial mediation between security \& privacy dimension, ecustomer satisfaction, and e-customer loyalty.

H8C: Religiosity has an affirmative \& significant serial mediation between fulfillment dimension, e-customer satisfaction, and e-customer loyalty.

H8D: Religiosity has an affirmative \& significant serial mediation between the availability of online system dimension, e-customer satisfaction, and e-customer loyalty.

H8E: Religiosity has an affirmative \& significant serial mediation between personal needs dimension, e-customer satisfaction, and e-customer loyalty.

H8F: Religiosity has a significant and positive mediation between e-customer satisfaction and e-customer loyalty.

\section{Material and Methods}

\section{Scaling and Research Design}

This study is quantitative and cross-sectional; we incorporated a modified E-S-QUAL model with two new dimensions: 1) the availability of the online system and 2) the customer's personal needs as independent factors. Additionally, we employed two mediating variables: religiosity and trust in e-Islamic banking customer satisfaction and loyalty. We used modified items (scales) from the previous literature; for instance, scales of ecustomer loyalty are considered from Ahmed et al. (2020), Zeithaml et al. (2002), Samsudeen et al. (2020), Evanschitzky et al. (2004), Al Qaisi and Alrosan (2020), Azizah and Puspito (2021), Lodhi (2020), and Iqbal (2020). 
The adapted scales of e-customer satisfaction were taken as a second-order PLS-SEM from the dimensions (efficiency, security \& privacy, fulfillment, availability of online system, and personal needs). However, the items of modified constructs are taken from previous literature; for instance, items of efficiency were extracted from Raza et al. (2019), Aghdaie et al. (2015), Ahmed et al. (2019), Butt (2018), Ali and Raza (2017), items (scales) of security \& privacy were considered from Ahmed et al. (2020), Yaseen and Kamran (2019), and Raza et al. (2019). The Modified items of fulfillment and availability of online system were considered from Raza et al. (2020), Lodhi (2020), Wu and Chang (2013), Ahmed et al. (2020), Chen and Hitt (2002), Ali and Raza (2017), and Kheng et al. (2010). However, the modified scales of personal needs were acquired from Shaharudin et al. (2010), Yaseen and Kamran (2019), Dusuki and Abdullah (2007), and Ahmed et al. (2020). Though the modified measurement scales of religiosity were considered from Bukhari et al. (2020), Rakrachakarn et al. (2015), Vitell (2009), and Ahmed et al. (2019), and adapted items of trust were taken from Ahmed et al. (2017), Fang et al. (2011), Yousafzai et al. (2009) Dimitriadis et al. (2011), Godwin et al. (2010), Ahmad and Al-Zubi (2011), and Crumlish and Malone (2009).

\section{Data Collection and Sampling Strategy}

The customer survey was conducted from the top five Islamic banks well-versed in online banking and currently taking benefits of e-Islamic banking services. We selected five prestigious and top Pakistani Islamic banks and contacted the customers using the purposive sampling technique through the online and offline procedure. We used a modified five-point Likert scale questionnaire and employed it through emails, social media (LinkedIn), and in-person through personal contacts. We have collected a total of 674 complete responses. Though, we had floated 800 questionnaires. We received 211 replies from Karachi city, 135 responses from Lahore, and 101 from Islamabad/Rawalpindi. However, 56 responses were collected from Multan city, 47 responses from Peshawar, 27 responses from Quetta, 39 from Hyderabad, and 48 responses from Faisalabad. Thus, in this way, we have covered almost all the urban centres of Pakistan.

\section{Estimation Techniques and Software}

We employed partial least square-structural equation modeling (PLS-SEM) using the software, Smart-PLS 3.1.6 to examine the survey data (Ringle et al., 2015). In the first step, we examine the measurement model and then evaluate the structural model in the second phase for the analysis purpose. However, first, we analysed the descriptive statistics of all the constructs. We measured Cronbach's alpha, average variance extracted and composite reliability of each construct, and factor loading of each item to evaluate the measurement model. First, we measured the discriminant and convergent validities using cross-loading, HTMT, and Fornell and Larcker's (1981) methods. Thus, in this way, we evaluated the hypothesized measurement model. However, the second phase examined the structural model using the R-square of individual endogenous variables, path co-efficient analysis. Through path co-efficient analyses, we also examined the direct impact between independent and dependent variables. Additionally, we measured the serial mediation through PLSSEM (path co-efficient analyses) using Smart-PLS (Ahmed et al., 2019). Finally, we established the validation of a hypothesized structural model of e-customer satisfaction and e-customer loyalty through Stone-Geisser $\left(Q^{2}\right)$ and SRMR indicators.

\section{Respondents' Demography}

We selected 674 responses; however, we had floated 800 questionnaires, but the rest of the responses was found inadequate and incomplete. Thus, the response rate was $84.25 \%$. For the employing of PLS-SEM, 674 are a sufficient sample (Ahmed et al., 2017). The findings of the Table 1 demonstrate the demographic analyses of respondents. The results showed that we had taken $366(54.30 \%)$ male respondents and 308 $(45.70 \%)$ females respondents. Table 1 exhibited the details of the entire demographic statistics.

\section{Estimations and Data Analysis}

We employed partial least square-structural equation modeling (PLS-SEM) using the software, Smart-PLS 3.1.6 to examine the survey data (Ringle et al., 2015). We examine the measurement model in the first step for the analysis purpose and then evaluate the structural model in the second step. However, first, we analysed the descriptive statistics of all the constructs.

\section{Descriptive Statistics}

We have analysed descriptive statistics of all the constructs to measure the initial characteristics of considered factors. First, we had converted data into zscores and then drawn different statistics, for instance, standard deviation (SD), skewness (SK), and kurtosis. The outcomes of Table 2 exhibited that our collected data followed the central limit theorem, and data showed the normality pattern (SD\&SK ranged \pm 1.5 and kurtosis ranged \pm 3 ). Hence, we can now proceed with further analysis of PLS-SEM (Raza et al., 2020; Lu et al., 2020).

Table 1

Respondents' Demographic Profile

\begin{tabular}{llcc}
\hline & Demographics & Frequency & Per cent \\
\hline \multirow{2}{*}{ Gender } & Male & 366 & $54.30 \%$ \\
& Female & 308 & $45.70 \%$ \\
\hline \multirow{2}{*}{ Marital Status } & Single & 213 & $31.60 \%$ \\
& Married & 461 & $68.40 \%$ \\
\hline \multirow{2}{*}{ Age (In Years) } & $20-25$ & 134 & $19.88 \%$ \\
& $26-30$ & 164 & $24.33 \%$ \\
\hline
\end{tabular}




\begin{tabular}{|c|c|c|c|}
\hline & Demographics & Frequency & Per cent \\
\hline & $36-40$ & 120 & $17.80 \%$ \\
\hline & More than 40 & 87 & $12.91 \%$ \\
\hline \multirow{4}{*}{$\begin{array}{l}\text { Experience } \\
\text { (In Years) }\end{array}$} & $5-10$ & 187 & $27.74 \%$ \\
\hline & $11-15$ & 267 & $39.61 \%$ \\
\hline & $16-20$ & 154 & $22.85 \%$ \\
\hline & More than 20 & 66 & $9.79 \%$ \\
\hline \multirow{5}{*}{$\begin{array}{l}\text { Income } \\
(\text { In PKR *) }\end{array}$} & $20-30$ & 185 & $27.45 \%$ \\
\hline & $31-40$ & 172 & $25.52 \%$ \\
\hline & $41-50$ & 149 & $22.11 \%$ \\
\hline & $50-60$ & 90 & $13.35 \%$ \\
\hline & More than 60 & 78 & $11.57 \%$ \\
\hline \multirow{3}{*}{ Education } & Under Graduation & 204 & $30.27 \%$ \\
\hline & Graduation & 302 & $44.81 \%$ \\
\hline & Post-Graduation & 168 & $24.93 \%$ \\
\hline & Total $-\mathbf{N}$ & & \\
\hline
\end{tabular}

Source: Authors' calculations

\section{Measurement Model}

According to Hair et al. (2019), Raza et al. (2020), the PLS-SEM method consisted of two phases. The first phase was to examine the measurement model. For this purpose, we measured the individual factor loading (FL) of each item of constructs. We examined the average variance extracted (AVE), Cronbach's alpha (CA), and composite reliabilities (CR) of constructs. The outcomes of Table 2 and Figure 1 exhibit that the FLs of each item are more significant than
0.70. Likewise, the $\mathrm{CA}$, rho $\mathrm{A}$, and $\mathrm{CR}$ readings are also higher than 0.70 . Hence, the condition of convergent validity has been met (Hair et al., 2019; Ahmed et al., 2017). Additionally, the measures of AVE are more significant than 0.50 . Therefore, the discriminant validity of constructs is also satisfied (Ahmed et al., 2019; Fronell \& Lacrker, 1981). Hence, these outcomes showed the validation of the measurement model because initial conditions are met ( $\mathrm{Lu}$ et al., 2020).

Measurement Model and Descriptive Statistics

\begin{tabular}{|c|c|c|c|c|c|c|c|c|c|c|c|}
\hline & Constructs & Items & FL & $\mathrm{CA}$ & rho_A & $\mathrm{CR}$ & AVE & SD & SKE & KUR & ECS \\
\hline \multirow{10}{*}{ 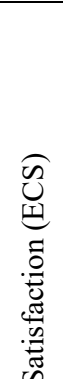 } & \multirow{3}{*}{ Efficiency } & EF1 & 0.852 & \multirow{3}{*}{0.722} & \multirow{3}{*}{0.740} & \multirow{3}{*}{0.843} & \multirow{3}{*}{0.643} & \multirow{3}{*}{1.101} & \multirow{3}{*}{-1.061} & \multirow{3}{*}{1.034} & \multirow{19}{*}{ 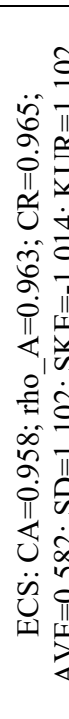 } \\
\hline & & EF2 & 0.722 & & & & & & & & \\
\hline & & EF3 & 0.826 & & & & & & & & \\
\hline & \multirow{5}{*}{$\begin{array}{c}\text { Security \& } \\
\text { Privacy }\end{array}$} & SP1 & 0.811 & \multirow{5}{*}{0.873} & \multirow{5}{*}{0.883} & \multirow{5}{*}{0.908} & \multirow{5}{*}{0.663} & \multirow{5}{*}{1.009} & \multirow{5}{*}{-1.181} & \multirow{5}{*}{1.152} & \\
\hline & & SP2 & 0.862 & & & & & & & & \\
\hline & & SP3 & 0.771 & & & & & & & & \\
\hline & & SP4 & 0.868 & & & & & & & & \\
\hline & & SP5 & 0.754 & & & & & & & & \\
\hline & \multirow{4}{*}{ Fulfillment } & FUL1 & 0.874 & \multirow{4}{*}{0.829} & \multirow{4}{*}{0.839} & \multirow{4}{*}{0.888} & \multirow{4}{*}{0.666} & \multirow{4}{*}{1.107} & \multirow{4}{*}{-1.031} & \multirow{4}{*}{1.053} & \\
\hline & & FUL2 & 0.796 & & & & & & & & \\
\hline in & & FUL3 & 0.683 & & & & & & & & \\
\hline $\mathscr{\Xi}$ & & FUL4 & 0.896 & & & & & & & & \\
\hline ర్ల & & AOS1 & 0.907 & & & & & & & & \\
\hline$\Xi^{n}$ & $\begin{array}{l}\text { Avallability } \\
\text { of Online }\end{array}$ & AOS2 & 0.769 & & & & & & & & \\
\hline 吉 & $\begin{array}{l}\text { of Unline } \\
\text { System }\end{array}$ & AOS3 & 0.885 & 0.842 & 0.852 & 0.895 & 0.682 & 1.106 & -1.011 & 1.109 & \\
\hline & & AOS4 & 0.729 & & & & & & & & \\
\hline & & PN1 & 0.838 & & & & & & & & \\
\hline & $\begin{array}{l}\text { Personal } \\
\text { Needs }\end{array}$ & PN2 & 0.829 & 0.698 & 0.722 & 0.816 & 0.600 & 1.172 & -1.091 & 1.062 & \\
\hline & & PN3 & 0.641 & & & & & & & & \\
\hline & & REL1 & 0.772 & & & & & & & & \\
\hline & Religiosity & REL2 & 0.877 & 0.791 & 0.797 & 0.878 & 0.707 & 1.061 & -1.004 & 1.011 & \\
\hline & & REL3 & 0.869 & & & & & & & & \\
\hline & & TRU1 & 0.720 & & & & & & & & \\
\hline & & TRU2 & 0.709 & & & & & & & & \\
\hline & & TRU3 & 0.726 & & & & & & & & \\
\hline & Trust & TRU4 & 0.705 & 0.854 & $0.8 / 2$ & 0.886 & 0.568 & 1.091 & -1.215 & 1.055 & \\
\hline & & TRU5 & 0.809 & & & & & & & & \\
\hline & & TRU6 & 0.839 & & & & & & & & \\
\hline & & ECL1 & 0.953 & & & & & & & & \\
\hline & & ECL2 & 0.838 & & & & & & & & \\
\hline $\mathrm{E}-\mathrm{C}$ & ustomer Loyalty & ECL3 & 0.755 & 0.935 & 0.943 & 0.952 & 0.796 & 1.071 & -1.221 & 1.105 & \\
\hline & & ECL4 & 0.951 & & & & & & & & \\
\hline & & ECL5 & 0.946 & & & & & & & & \\
\hline
\end{tabular}

Source: Authors' calculations 


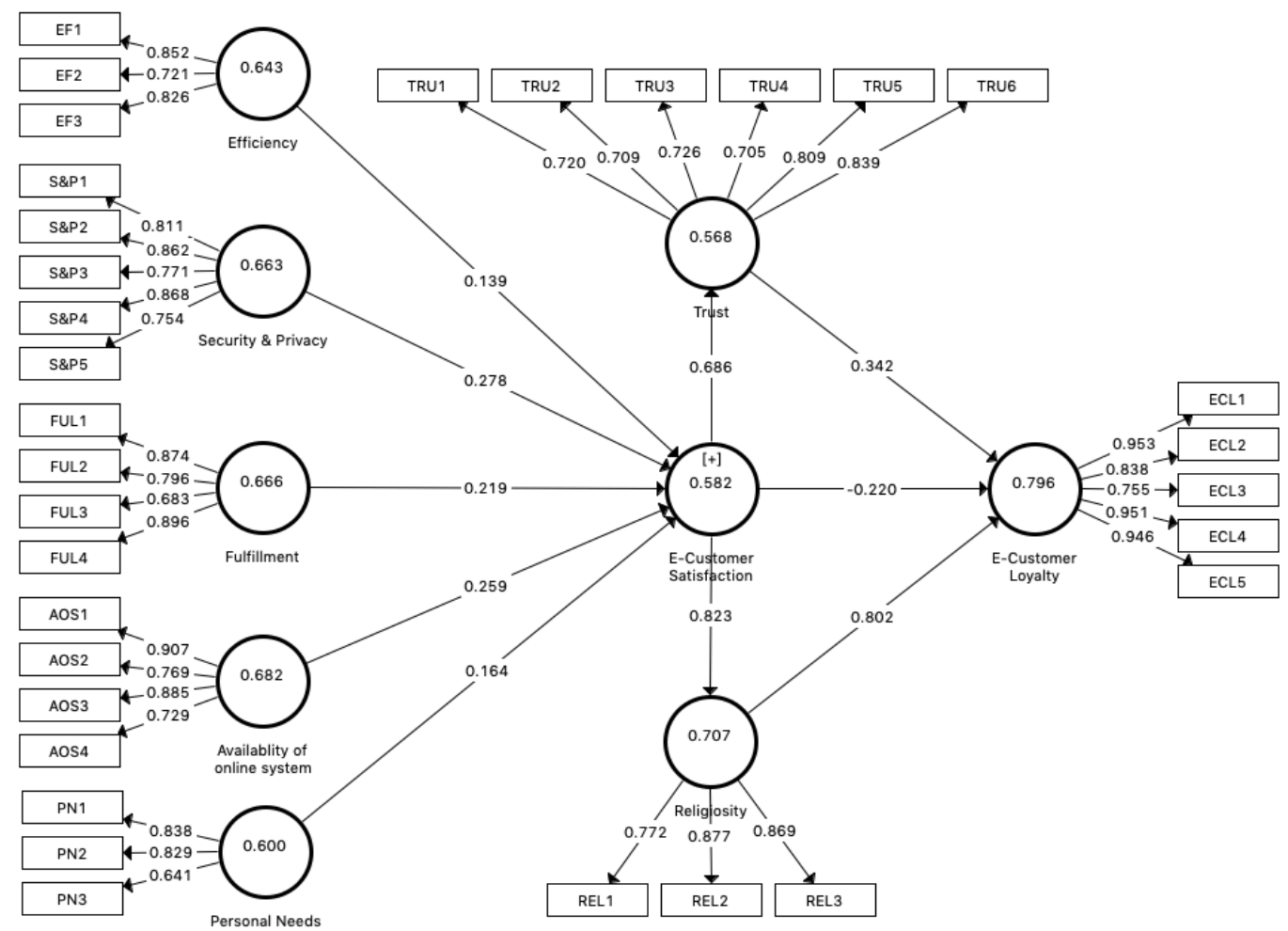

Figure 1. Smart-PLS - Factor Loading \& Average Variance Extracted (Modified E-S-QUAL Model) Source: Authors' calculations

The Fornell and Larkers (1981) criterion examined the discriminant validity; this method provided the square root values of AVE. The readings are provided in a diagonal (highlighted in Table 3), and these readings are more significant than the correlation of other variables. Thus, the discriminant validity of constructs has been met. Therefore, it is established that the considered measurement model is valid for the hypothesized modified E-S-QUAL model.

Table 3

The Fornell-Larcker (1981) Criterion - Discriminant Validity

\begin{tabular}{l|c|c|c|c|c|c|c|c|c}
\hline \multicolumn{1}{c|}{ Constructs } & AOS & ECL & ECS & EF & FUL & PN & REL & SP & TRU \\
\hline Availability of the online system & $\mathbf{0 . 8 2 6}$ & & & & & & & & \\
\hline E-Customer Loyalty & 0.729 & $\mathbf{0 . 8 9 2}$ & & & & & & \\
\hline E-Customer Satisfaction & 0.749 & 0.675 & $\mathbf{0 . 7 6 3}$ & & & & & & \\
\hline Efficiency & 0.814 & 0.596 & 0.674 & $\mathbf{0 . 8 0 2}$ & & & & & \\
\hline Fulfillment & 0.818 & 0.617 & 0.665 & 0.720 & $\mathbf{0 . 8 1 6}$ & & & & \\
\hline Personal Needs & 0.798 & 0.639 & 0.730 & 0.771 & 0.791 & $\mathbf{0 . 7 7 5}$ & & & \\
\hline Religiosity & 0.809 & 0.804 & 0.723 & 0.758 & 0.753 & 0.693 & $\mathbf{0 . 8 4 1}$ & & \\
\hline Security \& Privacy & 0.773 & 0.575 & 0.719 & 0.715 & 0.746 & 0.685 & 0.758 & $\mathbf{0 . 8 1 5}$ & \\
\hline Trust & 0.706 & 0.854 & 0.686 & 0.591 & 0.634 & 0.757 & 0.827 & 0.558 & $\mathbf{0 . 7 5 3}$ \\
\hline
\end{tabular}

Source: Authors' calculations

The loading and cross-loading analyses are other criteria to measure discriminant validity that support the measurement model. The findings of Table 4 exhibited that the cross-loading difference is higher than 0.1 , and loadings of every single item of a construct are more significant than the other items of constructs as highlighted in rows and columns (Raza et al., 2020). Hence, it is confirmed the validation of hypothesized measurement model of modified E-S-QUAL dimensions.

Cross Loadings

\begin{tabular}{l|c|c|c|c|c|c|c|c}
\hline Indicators & AOS & ECL & EF & FUL & PN & REL & SP & TRU \\
\hline AOS1 & $\mathbf{0 . 9 0 7}$ & 0.553 & 0.820 & 0.863 & 0.790 & 0.611 & 0.617 & 0.553 \\
\hline AOS2 & $\mathbf{0 . 7 6 9}$ & 0.498 & 0.727 & 0.730 & 0.680 & 0.724 & 0.638 & 0.509 \\
\hline AOS3 & $\mathbf{0 . 8 8 5}$ & 0.498 & 0.764 & 0.832 & 0.779 & 0.530 & 0.551 & 0.518 \\
\hline AOS4 & $\mathbf{0 . 7 2 9}$ & 0.639 & 0.570 & 0.575 & 0.590 & 0.550 & 0.523 & 0.505 \\
\hline ECL1 & 0.720 & $\mathbf{0 . 9 5 3}$ & 0.571 & 0.578 & 0.587 & 0.865 & 0.533 & 0.803 \\
\hline ECL2 & 0.624 & $\mathbf{0 . 8 3 8}$ & 0.540 & 0.603 & 0.649 & 0.761 & 0.535 & 0.811 \\
\hline
\end{tabular}


Rizwan Raheem Ahmed, Dalia Streimikiene, Zahid Ali Channar, Riaz Hussain Soomro, Justas Streimikis. E-Banking...

\begin{tabular}{|c|c|c|c|c|c|c|c|c|}
\hline Indicators & AOS & ECL & EF & FUL & PN & REL & SP & TRU \\
\hline ECL3 & 0.518 & 0.755 & 0.435 & 0.427 & 0.461 & 0.609 & 0.413 & 0.610 \\
\hline ECL4 & 0.692 & 0.951 & 0.562 & 0.556 & 0.565 & 0.838 & 0.542 & 0.782 \\
\hline ECL5 & 0.675 & 0.946 & 0.536 & 0.563 & 0.569 & 0.821 & 0.523 & 0.778 \\
\hline EF1 & 0.758 & 0.508 & 0.852 & 0.730 & 0.795 & 0.748 & 0.764 & 0.506 \\
\hline EF2 & 0.484 & 0.359 & 0.721 & 0.593 & 0.461 & 0.427 & 0.649 & 0.341 \\
\hline EF3 & 0.808 & 0.547 & 0.826 & 0.669 & 0.794 & 0.615 & 0.603 & 0.551 \\
\hline FUL1 & 0.807 & 0.556 & 0.719 & 0.874 & 0.812 & 0.627 & 0.563 & 0.593 \\
\hline FUL2 & 0.750 & 0.523 & 0.686 & 0.796 & 0.584 & 0.746 & 0.654 & 0.546 \\
\hline FUL3 & 0.506 & 0.384 & 0.691 & 0.683 & 0.486 & 0.452 & 0.562 & 0.381 \\
\hline FUL4 & 0.796 & 0.532 & 0.802 & 0.896 & 0.787 & 0.605 & 0.593 & 0.529 \\
\hline PN1 & 0.808 & 0.535 & 0.703 & 0.739 & 0.838 & 0.588 & 0.546 & 0.591 \\
\hline PN3 & 0.775 & 0.511 & 0.751 & 0.737 & 0.829 & 0.754 & 0.650 & 0.531 \\
\hline PN3 & 0.421 & 0.446 & 0.360 & 0.412 & 0.641 & 0.458 & 0.320 & 0.547 \\
\hline REL1 & 0.465 & 0.520 & 0.546 & 0.637 & 0.707 & 0.772 & 0.659 & 0.533 \\
\hline REL2 & 0.661 & 0.818 & 0.547 & 0.554 & 0.547 & 0.877 & 0.534 & 0.749 \\
\hline REL3 & 0.625 & 0.817 & 0.542 & 0.624 & 0.666 & 0.869 & 0.543 & 0.792 \\
\hline SP1 & 0.646 & 0.502 & 0.711 & 0.678 & 0.642 & 0.625 & 0.811 & 0.465 \\
\hline SP2 & 0.723 & 0.544 & 0.773 & 0.765 & 0.753 & 0.757 & 0.862 & 0.542 \\
\hline SP3 & 0.489 & 0.385 & 0.675 & 0.667 & 0.483 & 0.464 & 0.771 & 0.374 \\
\hline SP4 & 0.756 & 0.511 & 0.844 & 0.729 & 0.789 & 0.743 & 0.868 & 0.504 \\
\hline SP5 & 0.488 & 0.372 & 0.713 & 0.592 & 0.474 & 0.438 & 0.754 & 0.360 \\
\hline TRU1 & 0.406 & 0.446 & 0.360 & 0.390 & 0.580 & 0.453 & 0.345 & 0.720 \\
\hline TRU2 & 0.397 & 0.422 & 0.347 & 0.413 & 0.497 & 0.451 & 0.357 & 0.709 \\
\hline TRU3 & 0.506 & 0.479 & 0.448 & 0.438 & 0.621 & 0.489 & 0.373 & 0.726 \\
\hline TRU4 & 0.388 & 0.417 & 0.339 & 0.394 & 0.495 & 0.430 & 0.347 & 0.705 \\
\hline TRU5 & 0.717 & 0.745 & 0.560 & 0.563 & 0.583 & 0.736 & 0.517 & 0.809 \\
\hline TRU6 & 0.619 & 0.646 & 0.519 & 0.582 & 0.645 & 0.636 & 0.501 & 0.839 \\
\hline
\end{tabular}

Source: Authors' calculations

Additionally, the findings of Table 5 demonstrate the analyses of the Heterotrait-Monotrait (HTMT) ratio of correlation. The HTMT should be less than 0.85 (Henseler et al., 2015) since the values of the HTMT ratio of correlation of constructs are less than 0.85 . Therefore, both convergent and discriminant validity criteria are met, and our considered hypothesized measurement model is validated for e-customer loyalty and e-customer satisfaction.

Heterotrait-Monotrait (HTMT) Ratio

\begin{tabular}{l|r|r|r|r|r|r|r|r|r}
\hline \multicolumn{1}{c|}{ Constructs } & AOS & \multicolumn{1}{c|}{ ECL } & \multicolumn{1}{c|}{ ECS } & EF & FUL & PN & REL & SP & TRU \\
\hline Availability of the online system & & & & & & & & & \\
\hline E-Customer Loyalty & 0.849 & & & & & & & & \\
\hline E-Customer Satisfaction & 0.841 & 0.711 & & & & & & & \\
\hline Efficiency & 0.837 & 0.715 & 0.765 & & & & & & \\
\hline Fulfillment & 0.781 & 0.695 & 0.683 & 0.784 & & & & & \\
\hline Personal Needs & 0.632 & 0.802 & 0.804 & 0.649 & 0.728 & & & & \\
\hline Religiosity & 0.815 & 0.736 & 0.849 & 0.838 & 0.832 & 0.764 & & & \\
\hline Security \& Privacy & 0.782 & 0.627 & 0.707 & 0.762 & 0.801 & 0.840 & 0.706 & & \\
\hline Trust & 0.802 & 0.770 & 0.736 & 0.707 & 0.721 & 0.756 & 0.829 & 0.611 & \\
\hline
\end{tabular}

Source: Authors' calculations

\section{Structural Model}

We have evaluated the structural model through path analyses between constructs, evaluation of $\mathrm{R}^{2}$, predictive relevance $\left(\mathrm{Q}^{2}\right)$, and SRMR measurement. The findings of Table 6 and Figure 2 exhibited R-square values that confirmed the goodness of fitness of the structural model. Figure 2 showed that the percent of change in endogenous factor due to the independent variables measured $\mathrm{R}^{2}$. Table 6 demonstrates that $87.0 \%$ variation in e-customer loyalty is experienced due to e-customer satisfaction, religiosity, and trust. Similarly, the coefficient of determination $\left(\mathrm{R}^{2}\right)$ of religiosity is $69.2 \%$, and trust is $48.8 \%$, revealing the change in religiosity and trust due to the respective independent variables. However, e-customer satisfaction experienced $100 \%$ change because of the second-order variable, and it is derived from the similar items of modified E-S-QUAL dimensions. The second step for evaluating the structural model is to evaluate the direct and indirect relationship (serial mediation) between the variables through co-efficient analysis. 
Table 6

R-Square and R-Square Adjusted

\begin{tabular}{l|c|c}
\hline \multicolumn{1}{c|}{ Factors } & R Square & R Square Adjusted \\
\hline E-Customer Loyalty & 0.870 & 0.867 \\
\hline E-Customer Satisfaction & 1.000 & 1.000 \\
\hline Religiosity & 0.692 & 0.677 \\
\hline Trust & 0.488 & 0.469 \\
\hline
\end{tabular}

Source: Authors' calculations

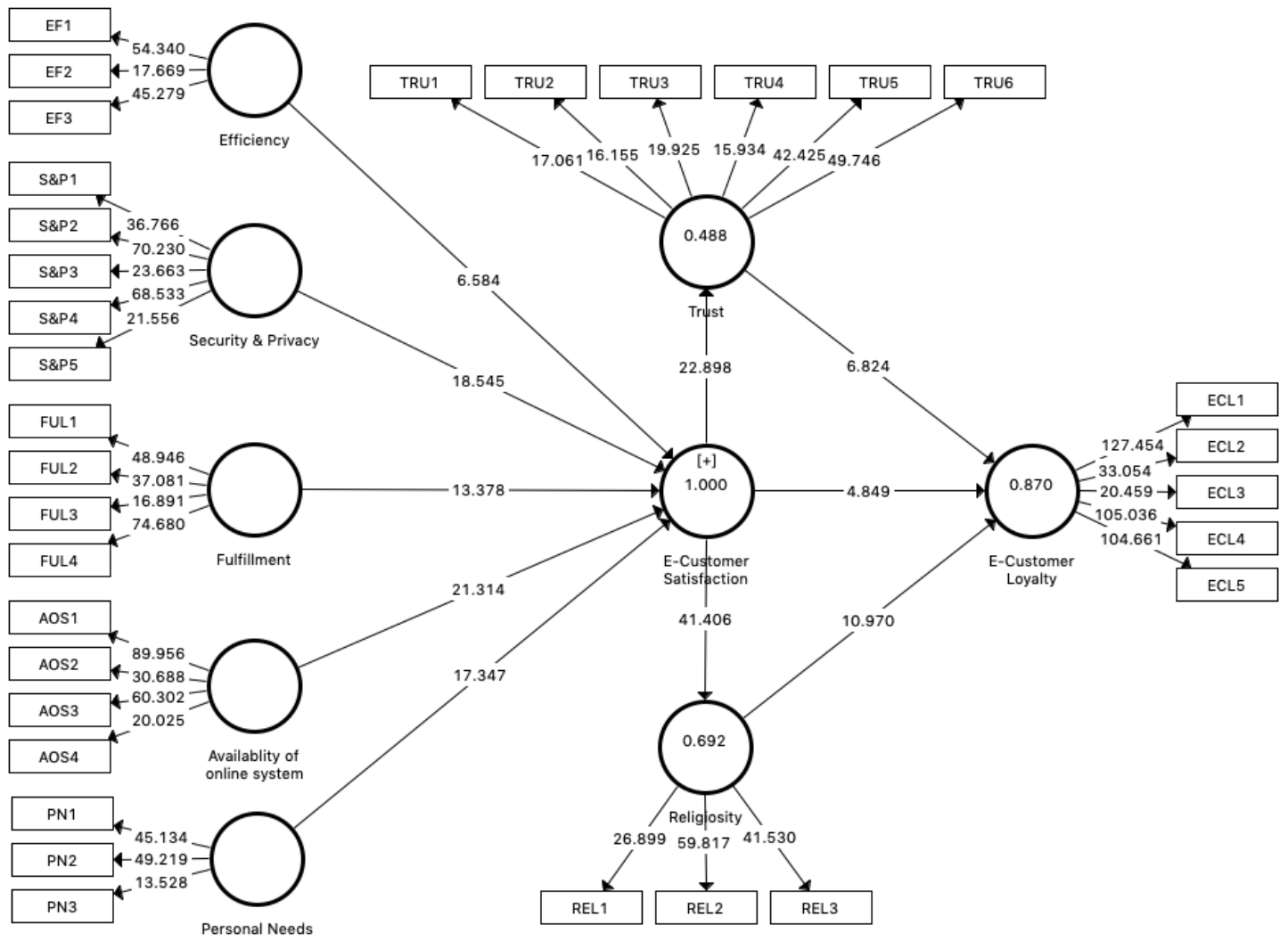

Figure 2. Smart-PLS - Path Analyses with R-Square Values (Modified E-S-QUAL Model) Source: Authors' calculations

\section{Postulated Direct Association}

The direct association between independent and dependent variables was analysed, and results are reported in Table 7. Additionally, the path co-efficient (standardized regression weights) also validated the structural model between the independent and dependent variables. Similarly, Figure 2 also demonstrated the T-values of a direct and indirect relationship between the variables. The findings of Table 7 exhibited that efficiency, security \& privacy, availability of the online system, and fulfillment have a positive and significant influence on e-customer satisfaction (ECS). Similarly, e-customers have a linear and an affirmative relationship with e-customer loyalty (ECL). Hence, it is conclusively established that $\mathrm{H} 1$ to $\mathrm{H} 6$ is substantiated because of the significance values $(p<0.01)$ and $\mathrm{T}$-values $(\mathrm{T} \pm>1.96)$. However, security \& privacy has the highest impact of $29.30 \%$ on e-customer satisfaction, and the availability of online system has an equal significance with $29.30 \%$ for the e-customer satisfaction. It is also concluded from Table 7 that e-customer satisfaction is directly translated into e-customer loyalty as ECS has an impact of $22.40 \%$ on ECL.

Postulated Direct Association

Table 7

\begin{tabular}{c|l|c|c|c|c}
\hline Hypotheses & \multicolumn{1}{|c|}{$\begin{array}{c}\text { Direct Path } \\
\text { Analyses }\end{array}$} & $\begin{array}{c}\text { Standardized } \\
\text { Regression Weights }\end{array}$ & T-Statistics & P-Values & Decision \\
\hline H1 & EF -> ECS & 0.098 & 6.584 & $0.000^{* *}$ & Supported \\
\hline H2 & SP -> ECS & 0.293 & 18.545 & $0.000^{* *}$ & Supported \\
\hline H3 & FUL -> ECS & 0.197 & 13.378 & $0.000^{* *}$ & Supported \\
\hline H4 & AOS -> ECS & 0.293 & 21.314 & $0.000^{* *}$ & Supported \\
\hline H5 & PN -> ECS & 0.180 & 17.347 & $0.000^{* *}$ & Supported \\
\hline H6 & ECS -> ECL & 0.224 & 4.849 & $0.000^{* *}$ & Supported \\
\hline
\end{tabular}

Note: Null Hypotheses Rejected at ${ }^{* *} p<0.01$

Source: Authors' calculations 


\section{Serial Mediation Analyses}

We employed bootstrapping method to examine the serial mediation of religiosity and trust through the serial path of e-customer satisfaction with e-customer loyalty (Ahmed et al., 2019). The findings of Table 8 exhibited that religiosity and trust have a positive and significant mediating influence between dimensions of the modified ES-QUAL model, for instance, security \& privacy, efficiency, fulfillment, availability of the online system, and personal needs, and e-customer loyalty through serial mediation of e-customer satisfaction. Hence, it is finally concluded that hypotheses H7A to H7E are accepted and retained because $\mathrm{T}> \pm 1.96 \& \mathrm{p}<0.01$, and a value of zero does not occur between the lower and upper interval of BCCI (Hayes \& Rockwood, 2020). Similarly, hypotheses $\mathrm{H} 8 \mathrm{~A}$ to $\mathrm{H} 8 \mathrm{E}$ are also substantiated. Likewise, the findings of Table 8 also exhibited that religiosity and trust have a cogent and affirmative impact on e-customer satisfaction and e-customer loyalty. Hence, it is finally confirmed that hypotheses $\mathrm{H} 7 \mathrm{~F}$ and $\mathrm{H} 8 \mathrm{~F}$ are also validated.

Serial Mediation Analysis

\begin{tabular}{|c|c|c|c|c|c|c|}
\hline \multirow{2}{*}{ Hypotheses } & \multirow{2}{*}{$\begin{array}{l}\text { Serial Mediation } \\
\text { Path Analyses }\end{array}$} & \multirow{2}{*}{$\begin{array}{c}\text { Path } \\
\text { Coefficient }\end{array}$} & \multirow{2}{*}{$\begin{array}{c}\mathrm{T} \\
\text { Statistics } \\
\end{array}$} & \multirow{2}{*}{$\begin{array}{c}\mathrm{P} * * \\
\text { Values }\end{array}$} & \multicolumn{2}{|c|}{ BCCI } \\
\hline & & & & & $2.5 \%$ & $97.5 \%$ \\
\hline H7A & EF -> ECS -> REL -> ECL & 0.066 & 5.295 & 0.000 & 0.158 & 0.233 \\
\hline H7B & SP $->$ ECS $->$ REL $->$ ECL & 0.196 & 9.013 & 0.000 & 0.041 & 0.089 \\
\hline $\mathrm{H} 7 \mathrm{C}$ & FUL $->$ ECS $->$ REL $->$ ECL & 0.132 & 9.274 & 0.000 & 0.107 & 0.161 \\
\hline H7D & AOS -> ECS -> REL -> ECL & 0.196 & 10.346 & 0.000 & 0.097 & 0.146 \\
\hline H7E & PN $->$ ECS $->$ REL $->$ ECL & 0.120 & 9.765 & 0.000 & 0.550 & 0.793 \\
\hline $\mathrm{H} 7 \mathrm{~F}$ & ECS -> REL -> ECL & 0.670 & 10.844 & 0.000 & 0.156 & 0.240 \\
\hline H8A & EF $->$ ECS $->$ TRU $->$ ECL & 0.070 & 6.979 & 0.000 & 0.052 & 0.090 \\
\hline H8B & SP $->$ ECS $->$ TRU $->$ ECL & 0.024 & 4.482 & 0.000 & 0.014 & 0.034 \\
\hline $\mathrm{H} 8 \mathrm{C}$ & FUL -> ECS -> TRU -> ECL & 0.047 & 5.594 & 0.000 & 0.032 & 0.066 \\
\hline H8D & AOS $->$ ECS $->$ TRU $->$ ECL & 0.043 & 6.750 & 0.000 & 0.032 & 0.056 \\
\hline $\mathrm{H} 8 \mathrm{E}$ & PN $->$ ECS $->$ TRU $->$ ECL & 0.070 & 7.208 & 0.000 & 0.052 & 0.090 \\
\hline $\mathrm{H} 8 \mathrm{~F}$ & ECS -> TRU -> ECL & 0.240 & 7.100 & 0.000 & 0.177 & 0.309 \\
\hline
\end{tabular}

Note: Null Hypotheses Rejected at: **p<0.01; BCCI: Bias Corrected Confidence Interval Source: Authors' calculations

\section{Stone-Geisser $\left(Q^{2}\right)$ and SRMR indicator}

The outcomes of Table 9 exhibit that Stone-Geisser or the predictive relevance $\left(\mathrm{Q}^{2}\right)$ validated the predictive relevance of every endogenous model such as ECS, REL, TRU, and ECL (1.000, 0.678, $0.472 \& 0.457$ respectively), and their respective independent variables. The outcomes of Table 10 showed the SRMR indicators, such as saturated and estimated SRMR models. According to Henseler et al. (2015) and Raza et al. (2019), the saturated SRMR model is considered the best fit, which also validated the goodness of fit of the hypothesized structural model.

Table 9

Stone-Geisser $\left(Q^{2}\right)$

\begin{tabular}{c|c}
\hline Constructs & $\mathbf{Q}^{2}$ Predict \\
\hline ECS & 1.000 \\
EF & \\
SP & \\
FUL & \\
AOS & \\
PN & \\
REL & 0.678 \\
TRU & 0.472 \\
ECL & 0.457 \\
\hline
\end{tabular}

Source: Authors' calculations

Table 10

SRMR Indicators

\begin{tabular}{c|c}
\hline Saturated Model & Estimated Model \\
\hline 0.061 & 0.166 \\
\hline
\end{tabular}

Source: Authors' calculations

\section{Discussions and Conclusion}

The current study has employed a modified E-S-QUAL model to evaluate e-customer satisfaction and e-customer loyalty. We have taken efficiency, fulfillment, security \& privacy, availability of the online system, and personal needs as the dimensions of the modified E-S-QUAL model. The study's findings exhibited that the dimension efficiency has a significant and positive association with e-customer satisfaction and e-customer loyalty. However, security \& privacy has the highest impact on e-customer satisfaction, and the availability of an online system has an equal significance for e-customer satisfaction. Preceding studies also depicted similar outcomes, for instance, Zouari and Abdelhedi (2021), Wu and Chang (2013), Chen and Hitt (2002), Kheng (2010), Raza et al. (2020), Yen and Lu (2008), Singh (2019), Ahmed et al. (2019), Sakhaei et al. (2014), Singh and Kaur (2013), Amin (2016), and Yaseen and Kamran (2019. The findings further demonstrated that fulfillment and personal needs are significantly and positively correlated with e-customer satisfaction and ecustomer loyalty in the perspective of Islamic e-banking services. The previous literature also confirmed similar results, for example, Sleimi et al. (2020), Suleman et al. (2012), Raza et al. (2019), Ho et al. (2012), Hammoud et al. (2018), Ahmed et al. (2020), and Amin (2016). Hence, it is confirmed that our hypothesized modified E-S-QUAL model is useful to assess the direct association between modified dimensions and e-customer satisfaction and ecustomer loyalty. Additionally, we had incorporated customer trust as a mediating factor between modified dimensions of the E-S-QUAL model and e-customer satisfaction and e-customer loyalty. The mediation 
outcomes exhibited that the customer trust has an affirmative and significant serial mediation between dimensions of the modified E-S-QUAL model and ecustomer satisfaction and e-customer loyalty. We also evaluated the mediating effect of trust between e-customer satisfaction and e-customer loyalty, which confirmed the mediation of trust between ECS and ECL. The results of the current study are consistent with preceding studies, such as Hayati et al. (2020), Dewi and Surabaya (2020), Mayer et al. (1995), Fang et al. (2011), Palvia (2009), Kim et al. (2009), Ahmed et al. (2017), Ali and Raza (2017), Godwin et al. (2010), Dimitriadis et al. (2011), Ahmad and Al-Zubi (2011), and Crumlish and Malone (2009). We also incorporated religiosity as a mediator in our considered modified E-S-QUAL model. The outcomes also verified that religiosity has a serial mediation in an association of modified E-S-QUAL dimensions, e-customer satisfaction, and e-customer loyalty. Finally, we examined the impact of religiosity as mediating factor between e-customer satisfaction and e-customer loyalty. The outcomes proved a significant and positive impact of religiosity as a mediator. These findings are also consistent with the previous literature, for instance, Tanim et al. (2021), Kumar and Mokha (2021), Bukhari et al. (2020), Ahmed et al. (2019), Dodds et al. (1991), Shaharudin et al. (2010), Dusuki and Abdullah (2007), Haron et al. (1994), and Rakrachakarn et al. (2015). The research results showed that the Islamic ebanking sector should increase awareness of their services, improve promotional and advertisement campaigns for long-run competitive growth. Moreover, Islamic banks should educate ordinary people that their products comply with Islamic Shariah values (Zouari \& Abdelhedi, 2021).

\section{Practical Contribution and Implications}

The research provides the basis for decision-making and strategies to improve the effectiveness of services of Islamic e-banking, especially for policymakers and higher management of Islamic banks. Islamic banks should consider customer's psychological variables to understand customer's acceptance of Islamic products. Besides, it is still necessary to recognize some essential elements aspiring to customer acceptance towards Islamic e-banking services. This will also boost the present situation for Islamic bank management, receiving more customers following Shariah law for e-banking services. The present and prospective customers of the Islamic products may increase product demand and help for anticipated e-customer satisfaction and e-customer loyalty.

Additionally, this research provides guidelines to the senior management of Islamic banks to devise novel strategies to compete with the conventional banking sector. The findings of the undertaken study provide two new dimensions, for instance, availability of the online system and personal needs as modified E-S-QUAL model. The proposed model helps the senior management of the Islamic banking sector integrate these two new dimensions for more competitive performance. Additionally, the findings demonstrated that religiosity and trust are predominant for customer satisfaction and loyalty. Thus, senior management of the Islamic banking sector may add religiosity and trust in their functional and marketing strategies.

\section{Theoretical Implications}

The undertaken study demonstrated important theoretical implications because it provides the fundamental foils to future researchers to replicate this modified model in different industries. Moreover, the derived modified conceptual model may help future researchers to carry out further studies in a different geographical context.

\section{Limitations and Future Areas of Research Studies}

The undertaken study has some specific limitations; for instance, we have taken only important urban centres of Pakistan. Therefore, it is recommended that future researchers may take more urban and semi-urban centres for more generalizable outcomes. We have taken only Pakistan to carry out this research; however, the prospective researcher may take more Islamic countries to confirm the modified model's robustness. This research could not check the causality between the variable. Thus, future studies may incorporate cause \& effect models. Finally, we have considered specific modified dimensions for the E-S-QUAL model and mediators; however, future researchers may take additional dimensions and mediators for more robust outcomes.

\section{Disclosure Statement}

There is no impending conflict of interest that the researchers have narrated.

\section{Funding}

The undertaken study does not get any funding.

\section{References}

Aghdaie, S. F. A., Karimi, R. \& Abasaltian, A. (2015). The evaluation of effect electronic banking in customer satisfaction and loyalty. International Journal of Marketing Studies, 7(2), 90-98. https://doi.org/10.5539/ijms.v7n2p90

Ahmad, A. E. M. K., \& Al-Zubi, H. A. (2011). E-banking functionality and outcomes of customer satisfaction: An empirical E-customization. International Journal of Market Studies, 3(1), 50-65. https://doi.org/10.5539/ijms.v3n1p50

Ahmed, R. R., Romeika, G., Kauliene, R., Streimikis, J., \& Dapkus, R. (2020). ES-QUAL Model and Customer Satisfaction in Online Banking: Evidence from Multivariate Analysis Techniques. Oeconomia Copernicana, 11(1), 55-89. https://doi.org/10.24136/oc.2020.003

Ahmed, R. R., Vveinhardt, J., \& Streimikiene, D. (2019). Application of the Theory of Planned Behaviour Model for Examining Customers' Intentions towards Islamic Hire Purchase Financing. Inzinerine Ekonomik-Engineering Economics, 30(2), 236-245. https://doi.org/10.5755/j01.ee.30.2.21589 
Ahmed, R. R., Vveinhardt, J., Streimikiene, D., Ashraf, M., \& Channar, Z. A. (2017). Modified SERVQUAL Model and Effects of Customer Attitude and Technology on Customer Satisfaction in Banking Industry: Mediation, Moderation, and Conditional Process Analysis. Journal of Business Economics and Management, 18(5), 974-1004. https://doi.org/10.3846/16111699.2017.1368034

Al Qaisi, F., \& Alrosan, M. (2020). Measuring Customers Satisfaction of Islamic Banking Sector in Jordan. Humanities and Social Sciences Letters, 8(3), 310-322. https://doi.org/10.18488/journal.73.2020.83.310.322

Ali, M., \& Raza, S. A. (2017). Service quality perception and customer satisfaction in Islamic banks of Pakistan: the modified SERVQUAL model. Total Quality Management \& Business Excellence, 28(5-6), 559-577. https://doi.org/10.10 80/14783363.2015.1100517

Amin, H., Rahman, A. R. A., \& Razak, D. A. (2014). Consumer acceptance of Islamic home financing. International Journal of Housing Markets and Analysis, 7(3), 307-332. https://doi.org/10.1108/IJHMA-12-2012-0063

Amin, M. (2016). Internet Banking Service Quality and Its Implication On E-Customer Satisfaction And E-Customer Loyalty. International Journal of Bank Marketing, 34(3), 280-306. https://doi.org/10.1108/IJBM-10-2014-0139

Azizah, N., \& Puspito, H. (2021). Satisfaction and Loyalty of Banking Customers in Indonesia. IPTEK The Journal of Engineering, 6(3), 63-72. https://doi.org/10.12962/j23378557.v6i3.a7654

Bauer, H. H., Hammerschmidt, M., \& Falk, T. (2005). Measuring the Quality of E-Banking Portals. International Journal of Bank Marketing, 23(2), 153-175. https://doi.org/10.1108/02652320510584395

Boateng, F., Adesi, M., Yeboah, E., Oduro, L. M., \& Sackey, M. M. (2021). Customer Satisfaction and Customer Loyalty in the Post-Crisis Banking Sector of Ghana. Journal of Marketing and Consumer Research, 76. https://doi.org/10.71 76/JMCR/76-04

Brodie, R. J. (2002). Service Management and Marketing: Customer Relationship Perspective. European Journal of Marketing, 36(9/10), 1164-1166. https://doi.org/10.1108/ejm.2002.36.9_10.1164.1

Bukhari, F., Hussain, S., Ahmed, R. R., Streimkiene, D., Soomro, R. H., \& Channar, Z. A. (2020). Motives and Role of Religiosity towards Consumer Purchase Behavior in Western Imported Food Products. Sustainability, $12(1), 356$. https://doi.org/10.3390/su12010356

Butt, M. (2018). E-banking system in Pakistan and its Impact on Customers Satisfaction: A Case Study of full-fledged Islamic Banks. COMSATS Journal of Islamic Finance, 3(2), 63-87. https://doi.org/10.26652/cjif.3201824

Caruana, A. (2002). Service Loyalty--The Effects of Service Quality and Mediating Role of Customer Satisfaction. European Journal of Marketing, 36(7/8), 811-828. https://doi.org/10.1108/03090560210430818

Chang, H. H., Wang, Y. H., \& Yang, W. Y. (2009). The impact of e-service quality, customer satisfaction and loyalty on emarketing: moderating effect of perceived value. Total Quality Management \& Business Excellence, 20(4), 423-443. https://doi.org/10.1080/14783360902781923

Chen, C. (2013). Perceived Risk, Usage Frequency of Mobile Banking Services. Managing Service Quality: An International Journal, 23(5), 410-436. https://doi.org/10.1108/MSQ-10-2012-0137

Chen, P. Y., \& Hitt, L. (2002). Measuring Switching Costs and Their Determinants in Internet-Enabled Businesses: A Study of the Online Brokerage Industry. Information Systems Research, 13(3), 255-276. https://doi.org/10.12 87/isre.13.3.255.78

Cronin, J. J., \& Taylor, S. A. (1992). Measuring Service Quality: A Re-Examination and Extensions. Journal of Marketing, 56(3), 55-68. https://doi.org/10.1177/002224299205600304

Crumlish, C., \& Malone, E. (2009). Designing Social Interfaces: Principles, Patterns and Practices for Improving the User Experience (1st Ed.), CA: US, O'Reilly Media, Inc.

Devaraj, S., Fan, M., \& Kohli, R. (2002). Antecedents of B2C Channel Satisfaction and Preference: Validating Ecommerce Metrics. Information System Research, 13(3), 316-333. https://doi.org/10.1287/isre.13.3.316.77

Dewi, L., \& Surabaya, U. C. (2020). Customer Loyalty, through Customer Satisfaction in Customers PT. XYZ. Jurnal Aplikasi Manajemen, 18(1), 189-200. https://doi.org/10.21776/ub.jam.2020.018.01.19. https://doi.org/10.21776/ ub.jam.2020.018.01.19

Dimitriadis, S., Kouremenos, A., \& Kyrezis, N. (2011). Trust-based segmentation: Preliminary evidence from technologyenabled bank channels. International Journal of Bank Marketing, 29(1), 5-31. https://doi.org/10.1108/026 52321111101356

Dodds, W. B., Monroe, K. B., \& Grewal, D. (1991). Effects of Price, Brand, and Store Information on Buyers' Product Evaluations. Journal of Marketing Research, 28(3), 307. https://doi.org/10.2307/3172866.

Dusuki, A. W., \& Abdullah, N. I. (2007). Why Do Malaysian Customers Patronise Islamic Banks? International Journal of Bank Marketing, 25(3), 142-160. https://doi.org/10.1108/02652320710739850 
Evanschitzky, H., Iyer, G. R., Hesse, J., \& Ahlert, D. (2004). E-satisfaction: A re-examination. Journal of Retailing, 80(3), 239-247. https://doi.org/10.1016/j.jretai.2004.08.002

Fang, Y. H., Chiu, C. M., \& Wang, E. T. G. (2011). Understanding customers' satisfaction and repurchase intentions: an integration of IS success model, trust, and justice. Internet Research, 21(4), 479-503. https://doi.org/10.11 08/10662241111158335

Flores, A. F., Saldanha, E. S., \& Vong, M. (2020). The Mediation Effect of Customer Satisfaction on the Relationship Between Service Quality and Customer Loyalty. Timor Leste Journal of Business and Management, 2, 56-65. https://doi.org/10.51703/bm.v2i2.22

Fornell, C., \& Larker, D. (1981). Structural equation modeling and regression: Guidelines for research practice. Journal of Marketing Research, 18(1), 39-50. https://doi.org/10.1177/002224378101800104

Gardener, E., Howcroft, B., \& Williams, J. (1999). The New Retail Banking Revolution. The Services Industries Journal, 19(2), 83-100. https://doi.org/10.1080/02642069900000020

Garzaro, D. M., Varotto, L. F., \& Pedro, S.d. C. (2020). Internet and mobile banking: the role of engagement and experience on satisfaction and loyalty. International Journal of Bank Marketing, 39(1), 1-23. https://doi.org/10.1108/IJBM-082020-0457

Godwin, J. U., Kallol, K. B., \& Peeter, J. K. (2010). An assessment of customers' e-service quality perception, satisfaction and intention. International Journal of Information Management, 30(6), 481-492. https://doi.org/10.10 16/j.ijinfomgt.2010.03.005

Hair, J., Risher, J., Sarstedt, M., \& Ringle, C. (2019). When to use and how to report the results of PLS-SEM. European Business Review, 31(1), 2-24. https://doi.org/10.1108/EBR-11-2018-0203

Hammoud, J., Bizri, R. M., \& El Baba, I. (2018). The impact of e-banking service quality on customer satisfaction: Evidence from the Lebanese banking sector. SAGE Open, 8(3). https://doi.org/10.1177/2158244018790633

Haron, S., Ahmed, N., \& Planisek, S. (1994). Bank patronage factors of Muslims and non-Muslim customers. International Journal of Bank Marketing, 12(1), 32-40. https://doi.org/10.1108/02652329410049599

Hayati, S., Suroso, A., Suliyanto, S., \& Kaukab, M. E. (2020). Customer satisfaction as a mediation between micro banking image, customer relationship and customer loyalty. Management Science Letters, 10, 2561-2570. https://doi.org/10. $5267 / \mathrm{j} . \mathrm{msl} .2020 .3 .039$

Hayes, A. F., \& Rockwood, N. J. (2020). Conditional process analysis: Concepts, computation, and advances in modeling of the contingencies of mechanisms. American Behavioral Scientist, 64(1), 19-54. https://doi.org/10.11 $77 / 0002764219859633$

Henseler, J., Ringle, C. M., \& Sarstedt, M. (2015). A new criterion for assessing discriminant validity in variance-based structural equation modeling. Journal of the Academy of Marketing Science, 43(1), 115-135. https://doi.org/10.10 07/s11747-014-0403-8

Ho, L. -A., Kuo, T. -H., \& Lin, B. (2012). The mediating effect of website quality on Internet searching behavior. Computers in Human Behavior, 28(3), 840-848. https://doi.org/10.1016/j.chb.2011.11.024

Iqbal T. (2020). An Assessment of the Impact that Service Quality and Customer Satisfaction Possess on Customer Loyalty in Internet Banking. International Journal of Online Marketing, 10(1), 58-71. https://doi.org/10.4018/IJOM. 2020010104

Keskar, M. Y., Pandey, N., \& Patwardhan, A. A. (2020). Development of conceptual framework for internet banking customer satisfaction index. International Journal of Electronic Banking, 2(1), 55-76. https://doi.org/10.1504/ IJEBANK.2020.105417

Khan, M. S., Mahapatra, S. S., \& Sreekumar. (2009). Service Quality Evaluation in Internet Banking: An Empirical Study in India. International Journal of Indian Culture and Business Management, 2(1), 30-46. https://doi.org/10.1504/ IJICBM.2009.021596

Kheng, L. L. (2010). The Impact of Service Quality on Customer Loyalty: A Study of Banks in Penang, Malaysia. International Journal of Marketing Studies, 2(2), 57-66. https://doi.org/10.5539/ijms.v2n2p57

Kim, D. J., Ferrin, D. L., \& Rao, H. R. (2009). Trust and satisfaction, two stepping-stones for successful eCommerce relationships: a longitudinal exploration. Information Systems Research, 20(2), 237-257. https://doi.org/10.12 87/isre. 1080.0188

Kumar, P., \& Mokha, A. K. (2021). Relationship between E-CRM, Customer Experience, Customer Satisfaction and Customer Loyalty in Banking Industry: A Review of Literature. RESEARCH REVIEW: International Journal of Multidisciplinary, 6(2), 127-137. https://doi.org/10.31305/rrijm.2020.v06.i02.022

Lodhi, R. N. (2020). Awareness, Understanding, and Usage of Islamic Banking Products and Services: A Case of Customers' Satisfaction Towards Islamic Banking in Pakistan. Islamic Banking and Finance Review, 7(1). https://doi.org/10.32 350/ibfr/2020/0700/757 
Lu, J., Ren, L., Zhang, C., Rong, D., Ahmed, R. R., \& Streimikis, J. (2020). Modified Carroll's Pyramid of Corporate Social Responsibility to Enhance Organizational Performance of SMEs Industry. Journal of Cleaner Production, 271, 122456. https://doi.org/10.1016/j.jclepro.2020.122456

Mahadin, B., Akroush, M. N., \& Bata, H. (2020). The effects of tourism websites' attributes on satisfaction and e-loyalty: A case of American travellers' to Jordan. International Journal of Web-Based Communities, 16(1), 4-33. https://doi.org/10.1504/IJWBC.2020.105124

Mayer, R. C., Davis, J. H., \& Schoorman, F. D. (1995). An integrative model of organizational trust. The Academy of Management Review, 20(3), 709-734. https://doi.org/10.2307/258792

Metawa, S. A., \& Al-Mossawi, M. (1998). Banking Behaviour of Islamic Bank Customers: Perspectives and Implications. International Journal of Bank Marketing, 16(7), 299-313. https://doi.org/10.1108/02652329810246028

Nguyen, N., \& Leblanc, G. (2002). Contact personnel, physical environment and the perceived corporate image of intangible services by new clients. International Journal of Service Industry Management, 13(3), 242-262. https://doi.org/10.11 08/09564230210431965

Palvia, P. (2009). The role of trust in e-commerce relational exchange: a unified model. Information \& Management, 46(4), 213-220. https://doi.org/10.1016/j.im.2009.02.003

Parasuraman, A., \& Zeithaml, V. A. (2002). Measuring and Improving Service Quality: A Literature Review and Research Agenda. In Handbook of marketing, Bart Weitz (Ed.), Thousand Oaks, CA: Sage.

Parasuraman, A., Zeithaml, V. A., \& Malhotra, A. (2005). E-S-QUAL: A Multiple-item Scale for Assessing Electronic Service Quality. Journal of Service Research, 7(3), 213-233. https://doi.org/10.1177/1094670504271156

Pikkarainen, K., Pikkarainen, T., Karjaluoto, H., \& Pahnila, S. (2006). The Measurement of End-User Computing Satisfaction of Online Banking Services: An Empirical Evidence from Finland. International Journal of Bank Marketing, 24(3), 158-172. https://doi.org/10.1108/02652320610659012

Rahmawati, R., \& Sentana, I. P. E. (2021). The Effect of Product Quality on Customer Loyalty with the Mediation of Customer Satisfaction. International Journal of Managerial Studies and Research, 9(2), 22-32. https://doi.org/10.20 431/2349-0349.0902004

Rajaobelina, L., Brun, I., \& Ricard, L. (2019). A classification of live chat service users in the banking industry. International Journal of Bank Marketing, 37(3), 838-857. https://doi.org/10.1108/IJBM-03-2018-0051

Rakrachakarn, V., Moschis, G. P., Ong, F. S., \& Shannon, R. (2015). Materialism and life satisfaction: The role of religion. Journal of Religion and Health, 54(2), 413-426. https://doi.org/10.1007/s10943-013-9794-y

Raza, S. A., Umer, A., Qureshi, M. A., \& Dahri, A. S. (2020). Internet banking service quality, e-customer satisfaction and loyalty: the modified e-SERVQUAL model. The TQM Journal, 32(6), 1443-1466. https://doi.org/10.1108/TQM-022020-0019

Raza, S. A., Jawaid, S. T., \& Hassan, A. (2015). Internet banking and customer satisfaction in Pakistan. Qualitative Research in Financial Markets, 7(1), 24-36. https://doi.org/10.1108/QRFM-09-2013-0027

Raza, S. A., Shah, N., \& Ali, M. (2019). Acceptance of mobile banking in Islamic banks: evidence from modified UTAUT model. Journal of Islamic Marketing, 10(1), 357-376. https://doi.org/10.1108/JIMA-04-2017-0038

Ringle, C. M., Wende, S., \& Becker, J. M. (2015). Smart-PLS 3.2.7. Smart-PLS GmbH.

Rodgers, W., Negash, S., \& Suk, K. (2005). The Moderating Effect of Online Experience on the Antecedents and Consequences of Online Satisfaction. Psychology \& Marketing, 22(4), 313-331. https://doi.org/10.1002/mar.20061

Sakhaei, S. F., Afshari, A. J., \& Esmaili, E. (2014). The Impact of Service Quality on Customer Satisfaction in Internet Banking. Journal of Mathematics and Computer Science. 9(1), 31-40. https://doi.org/10.22436/jmcs.09.01.04

Samsudeen, S. N., Selvaratnam, G., \& Mohamed, A. H. H. (2020). Intention to use mobile banking services: an Islamic banking customers' perspective from Sri Lanka. Journal of Islamic Marketing. https://doi.org/10.1108/JIMA-052019-0108

Santos, J. (2003). E-service quality: a model of virtual service quality dimensions. Managing Service Quality: An International Journal, 13(3), 233-246. https://doi.org/10.1108/09604520310476490

Shaharudin, M. R., Pani, J. J., Mansor, S. W., \& Elias, S. J. (2010). Purchase Intention of Organic Food in Kedah, Malaysia; A Religious Overview. International Journal of Marketing Studies, 2(1), 96-103. https://doi.org/10.5539/ ijms.v2n1p96

Shao, J., Rod, M., Ashill, N. J., \& Carruthers, J. (2009). An examination of the relationship between service quality dimensions, overall Internet banking service quality and customer satisfaction: A New Zealand study. Marketing Intelligence and Planning, 27(1), 103-126. https://doi.org/10.1108/02634500910928344

Sheng, T., \& Liu, C. (2010). An empirical study on the effect of e-service quality on online customer satisfaction and loyalty. Nankai Business Review International, 1(3), 273-283. https://doi.org/10.1108/20408741011069205 
Siam, A. Z. (2006). Role of the electronic banking services on the profits of Jordanian Banks. American Journal of Applied Science, 3(9), 1999-2004. https://doi.org/10.3844/ajassp.2006.1999.2004

Singh, J., \& Kaur, P. (2013). Customers' attitude towards technology based services provided by select Indian banks: empirical analysis. International Journal of Commerce and Management, 23(1), 56-68. https://doi.org/10.1108/ 10569211311301439

Singh, R. K. (2019). The Impact of E-Banking on the use of Banking Services and Customers Satisfaction. International Journal of Trend in Scientific Research and Development, 3(4), 20-23. https://doi.org/10.31142/ijtsrd23559

Siu, N. Y -M., \& Mou, J. C -W. (2005). Measuring Service Quality in Internet Banking: The Case of Hong Kong. Journal of International Consumer Marketing, 17(4), 99-116. https://doi.org/10.1300/J046v17n04_06

Sleimi, M., Musleh, M., \& Qubbaj, I. (2020). E-Banking services quality and customer loyalty: The moderating effect of customer service satisfaction: Empirical evidence from the UAE banking sector. Management Science Letters, 10, 3663-3674. https://doi.org/10.5267/j.msl.2020.6.027

Sohail, M. S., \& Shaikh, N. M. (2008). Internet Banking and Quality of Service: Perspectives from A Developing Nation in the Middle East. Online Information Review, 32(1), 58-72. https://doi.org/10.1108/14684520810865985

Suleman, G. P., Mat, K. N., Adasiyan, O. I., Muhammed, A. S., \& Alekum, J. (2012). Customer Loyalty in e-Banking: A Structural Equation Modelling (SEM) Approach. American Journal of Economics, 1(1), 55-59. https://doi.org/10.59 23/j.economics.20120001.13

Tanim, G. M. S., Rahman, M. Z., \& Islam, M. Z. (2021). Interfacing Relationship among Work Stress, Service Quality and Customer Satisfaction: Evidence from Banking Industry of Bangladesh. Journal of Economics and Sustainable Development, 12(4). https://doi.org/10.7176/JESD/12-4-04

Vinayek, R., \& Jindal, P. (2011). An Empirical Investigation of Key Antecedents of Customer Preference of Internet Banking in Indian Context. Asia Pacific Business Review, 7(3), 63-71. https://doi.org/10.1177/097324701100700306

Vitell, S. J. (2009). The role of religiosity in business and consumer ethics: A review of the literature. Journal of Business Ethics, 90(S2), 155-167. https://doi.org/10.1007/s10551-010-0382-8

Wu, H. -C., \& Cheng, C. -C. (2013). A hierarchical model of service quality in the airline industry. Journal of Hospitality and Tourism Management, 20, 13-22. https://doi.org/10.1016/j.jhtm.2013.05.001

Yaseen, Z., \& Kamran, S. (2019). Exploring the Impediments Faced by the Banking Customers to Adopt Islamic Banking Services in Pakistan. Journal of Islamic Business and Management, 9(1). https://doi.org/10.26501/jibm/2019.0901003

Yen, C. H., \& Lu, H. P. (2008). Effects of e-service quality on loyalty intention: an empirical study in online auction. Managing Service Quality, 18(2), 127-146. https://doi.org/10.1108/09604520810859193

Yoon, C. (2010). Antecedents Of Customer Satisfaction With Online Banking In China: The Effects Of Experience. Computers in Human Behavior. 26(6), 1296-1304. https://doi.org/10.1016/j.chb.2010.04.001

Yousafzai, S., Pallister, J., \& Foxall, G. (2009). Multidimensional role of trust in Internet banking adoption. The Service Industries Journal, 29(5), 591-605. https://doi.org/10.1080/02642060902719958

Zeithaml, V. A. (2002). Service excellence in electronic channels. Managing Service Quality: An International Journal, 12(3), 135-139. https://doi.org/10.1108/09604520210429187

Zeithaml, V. A., Parasuraman, A., \& Malhotra, A. (2000). A Conceptual Framework for Understanding E-Service Quality: Implication for Future Research and Managerial Practice. Working Paper No. 00-115, Marketing Science Institute, Cambridge, MA.

Zeithaml, V. A., Parasuraman, A., \& Malhotra, A. (2002). Service Quality Delivery through Web Sites: A Critical Review of Extant Knowledge. Journal of Academy of Marketing Science, 30(4), 362-375. https://doi.org/10.1177/ 009207002236911

Zouari, G., \& Abdelhedi, M. (2021). Customer satisfaction in the digital era: evidence from Islamic banking. Journal of Innovation and Entrepreneurship, 10(1). https://doi.org/10.1186/s13731-021-00151-x

The article has been reviewed.

Received in April 2021; accepted in October 2021.

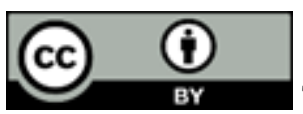

This article is an Open Access article distributed under the terms and conditions of the Creative Commons Attribution 4.0 (CC BY 4.0) License (http://creativecommons.org/licenses/by/4.0/). 